Bangladesh J. Zool. 40(1): 121-128, 2012

\title{
PHYTOPLANKTON DIVERSITY AND ABUNDANCE IN RELATION TO POLLUTION LEVELS IN THE HAZARIBAGH TANNERY EFFLUENT SEWAGE WATER OF THE RIVER BURIGANGA
}

\author{
Zannatul Ferdous, Sumi Akter ${ }^{1}$, Mahamudul Hasan, Rawshan Ara Begum \\ and Reza Md. Shahajahan* \\ Department of Zoology, University of Dhaka, Dhaka-1000, Bangladesh
}

\begin{abstract}
About 185 leather processing industries have been operating in Hazaribagh and discharging solid and liquid wastes to the downstream areas of the river Buriganga and to the canals around. The physico-chemical parameters and biological examination of tannery effluents sewage water were carried out in relation to phytoplankton abundance at four selected points (viz. Kamrangirchar: K1, K2 and K3; Hazaribagh Tempo Stand: H) of the Buriganga river from October 2009 to September 2010. Altogether 27 genera of Phytoplankton belonging to the families Cyanophyceae, Bacillariophyceae, Chlorophyceae, Euglenophyceae and Cryptophyceae were identified from the above points. Merismopedia was the most abundant form $\left(3.6 \times 10^{4}-2.4 \times 10^{6}\right.$ cell/L) compared to those $\left(1.4-72 \times 10^{3}\right.$ cell $\left./ 1\right)$ genera of other phytoplankton (Nitzschia, Synedra, Pleurosigma, Euglena, Strusastrum, Crucigenia, Ourococcus ) at K1, the station closest to the tannery effluent outfall. The abundance of Merismopedia increased gradually (K2: $6.45 \times 10^{4}$ - $3.68 \times 10^{6}, \mathrm{~K} 3: 6.95 \times 10^{4}-1.68 \times 10^{7}$ and $\mathrm{H}: 1.0 \times 10^{5}-2.06 \times 10^{7}$ ) along with the decreasing pollutant concentrations of the water.
\end{abstract}

Key words: Phytoplankton, Tannery effluent, Buriganga river, Pollution, Merismopedia, Cyanophyceae, Bacillariophyceae

\section{INTRODUCTION}

Hazaribagh is a densely populated area of Dhaka city where about 185 leather processing industries are operating and discharging solid and liquid wastes directly or indirectly to the low-lying areas, river and natural canals through two open drains without proper treatment. The water in the lowlying areas near Hazaribagh, with a direct link to the Buriganga river, is polluted in such a degree that it has become unsuitable for public uses. The river is seriously polluted by the discharge of industrial effluents (toxic Chemicals: hydrogen sulphide, ammonia, poisonous chlorine, heavy metals) into river water, indiscriminate throwing of household, clinical, pathological and commercial wastes, and discharge of fuel and human excreta. The water of the river has become so polluted that its aquatic life has almost been extinguished. A survey carried out in 1999 revealed that up to 40,000 tones of tannery waste flows into the river Buriganga, Turag, Dhaleshwari, Balu, and Narai daily along with sewage water (Arias et al. 2010). Phytoplanktons occupy the functional and

${ }^{*}$ Corresponding author: E-mail: reza_shahjahan@yahoo.com ${ }^{1}$ Environmental Microbiology Lab, ICDDR'B, Dhaka, Bangladesh. 
basic significance in the overall food web (Kalavati et al. 1997). Due to the pollution, phytoplankton population is affected and leading to drustic change in the food chain of the fresh water environment (Narendar 1990). Some phytoplankton species are often used as a good indicator of water quality and pollution. Studies revealed that there was an outburst of Skeletonema costatum as a result of pollution in Visakhaplanam harbor (Raman 1995). The phytoplankton community was stressed by the large and continues out flow from ElUmoum effluents (Dorgham 1997). So far no study was conducted in the Buriganga river to evaluate the relationship between phytoplankton and pollutants.

The aim of this work was to study the diversity and abundance of phytoplankton in relation to the level of pollution near Hazaribagh area of the Buriganga river.

\section{MATERIAL AND METHODS}

To evaluated the physical, chemical and biological variables, sampling was performed at four selected different points of Hazaribagh (Kamrangirchor) tannery complex area, located in Dhaka, Bangladesh $\left(23^{\circ} 43^{\prime} \mathrm{N}, 90^{\circ} 21^{\prime} \mathrm{E}\right)$. These points were $\mathrm{K} 1$ main tannery effluent discharging point (Companyghat), K2 about 100 meters north from K1 downstream location from the sluice gate, K3 about 150 meters from K2, and Hazaribagh tempo stand $(\mathrm{H})$ about 240 meters from K1 location from October 2009 to September, 2010. The water samples were collected in the morning between 7.00 a.m. and 9.00 a.m. Water temperature (by using a precise mercury thermometer), hydrogen ion concentration (by using a pH meter), electrical conductivity (with a conductivity meter), turbidity level (by using turbidity-meter) were recorded at the spot and the rest of the parameters were determined in the laboratory. Water samples were collected for chemical and biological analysis using pre-washed polyethylene bottle by water sample twice before filling and stored at $4^{\circ} \mathrm{C}$ in the laboratory. Following physiochemical parameters were measured in the laboratory: Dissolved oxygen (by using a DO meter), Biological oxygen demand, BOD (5-day BOD test), Chemical oxygen demand, COD (by sample digestion method), Phosphate (by using Standard Colorimetric method, ascorbic acid) (Apha 1998). Nitrite-nitrogen, Nitrate-nitrogen and Ammonia (by using spectrophotometric method) (Apha 1998). Collected algal samples were preserved in 4\% formalin and lugol's iodine solution. Algal identification was done by using a standard monograph (Anand 1998). 


\section{RESULTS}

Physicochemical parameters: Difference in the water quality and phytoplankton composition and abundant were observed between the highly polluted sites (K1, K2 \& K3) and the last point $\mathrm{H}$, which was comparatively less polluted (Table 1).

Table 1. Physico-chemical properties and phytoplankton diversity of Buriganga river from September 2009 to August 2010.

\begin{tabular}{lllll}
\hline Sampling parameters & $\begin{array}{l}\text { Sampling } \\
\text { point (K1) }\end{array}$ & $\begin{array}{l}\text { Sampling } \\
\text { point (K2) }\end{array}$ & $\begin{array}{l}\text { Sampling } \\
\text { point (K3) }\end{array}$ & $\begin{array}{l}\text { Sampling } \\
\text { point (H) }\end{array}$ \\
\hline Water Temperature $\left({ }^{\circ} \mathrm{C}\right)$ & $19-26$ & $18-26.5$ & $18.5-26$ & $17.8-26$ \\
$\mathrm{pH}$ & $6.00-7.54$ & $6.69-7.58$ & $6.80-7.79$ & $6.89-7.74$ \\
Dissolved Oxygen $(\mathrm{mg} / \mathrm{l})$ & $0.9-1.23$ & $1.0-1.19$ & $0.89-1.31$ & $1.35-1.89$ \\
Chemical Oxygen Demand (mg/l) & $59.56-66.48$ & $69.0-70.84$ & $50.65-54.49$ & $54.23-55.58$ \\
Biochemical Oxygen Demand (mg/1) & $10.23-12.55$ & $11.65-13.65$ & $9.0-11.75$ & $8.5-10.05$ \\
Turbidity (NTU) & $8.69-9.12$ & $7.65-8.78$ & $6.69-7.85$ & $6.52-7.65$ \\
Nitrate-Nitrogen $(\mathrm{mg} / 1)$ & $2.23-2.61$ & $2.85-3.45$ & $3.0-3.74$ & $3.23-4.22$ \\
Nitrite-Nitrogen $(\mathrm{mg} / \mathrm{l})$ & $0.23-0.52$ & $0.31-0.65$ & $0.56-0.72$ & $0.71-0.78$ \\
Phosphate $(\mathrm{mg} / \mathrm{l})$ & $4.65-5.03$ & $3.56-5.02$ & $0.23-0.86$ & $0.16-0.97$ \\
Conductivity $(\mu \mathrm{S} / \mathrm{cm})$ & $865-912$ & $866-902$ & $789-862$ & $856-899$ \\
Ammonia as Nitrogen $(\mathrm{mg} / \mathrm{l})$ & $5.81-6.13$ & $5.03-6.39$ & $4.96-6.51$ & $3.56-6.18$ \\
\hline
\end{tabular}

In points $\mathrm{K} 1, \mathrm{~K} 2$ and $\mathrm{K} 3$, the results obtained regarding physiochemical parameters revealed that the overall range of temperature was $18-26.5^{\circ} \mathrm{C}$, turbidity 6.69-9.12 NTU, pH 6.0-7.79, conductivity 789-912 $\mu \mathrm{S} / \mathrm{cm}$, dissolved oxygen 0.89-1.31 mg/1, Nitrite-Nitrogen $\left(\mathrm{NO}_{2}-\mathrm{N}\right)$ 0.23-0.72 mg/1, Nitrate-Nitrogen $\left(\mathrm{NO}_{3}-\mathrm{N}\right)$ 2.23-3.74 mg/l, ammonia $\left(\mathrm{NH}_{4}\right) 4.96-6.51 \mathrm{mg} /$, total phosphorus $0.23-$ $5.03 \mathrm{mg} / 1$, Chemical Oxygen Demand (COD) 50.65-70.84 mg/1 and Biological Oxygen demand (BOD) was 9.0-13.65 mg/1.

On the other hand, in point $\mathrm{H}$, temperature was $17.8-26 .{ }^{\circ} \mathrm{C}$, turbidity was 6.85-7.52 NTU which is remarkably less than that of $\mathrm{K} 1$, pH was 6.89-7.74 and conductivity $856-899 \mu \mathrm{S} / \mathrm{cm}$. Dissolve oxygen $(1.35-1.89 \mathrm{mg} / 1)$, inorganic nitrogen $\left(\mathrm{NO}_{2}-\mathrm{N}\right.$ 0.71-0.78 mg/1, $\left.\mathrm{NO}_{3}-\mathrm{N} 3.23-4.22 \mathrm{mg} / \mathrm{l}\right)$ were higher than the other three points. However, Biological Oxygen demand (BOD, 8.5-10.05 mg/1) was less than the rest of the points. Chemical Oxygen Demand (COD, 54.23$55.58 \mathrm{mg} / \mathrm{l})$, ammonia $\left(\mathrm{NH}_{4} 3.56-6.18 \mathrm{mg} / 1\right)$ and total phosphorus (0.16-0.97 $\mathrm{mg} / 1$ were more or less similar to $\mathrm{K} 1, \mathrm{~K} 2 \& \mathrm{~K} 3$.

Biological Characteristics: Altogether 27 genera of Phytoplankton belonging to families Cyanophyceae, Bacillariophyceae, Chlorophyceae, Euglenophyceae and Cryptophyceae were identified from these four points (Fig. 1 and Table 2) 
Merismopedia of Cyanophyceae was evidently the most abundant and frequent genera. The green algae (Chlorophyceae) were the more diverse group, and their diversity and abundance increased with the decrease of pollution. Notable genera of this group were Crucigenia, Ankistrodesmus, Tetradesmus, Clostridium, Coelostrum, Strusastrum, Ourococcus, Chlamydomonas, Senedesmus.
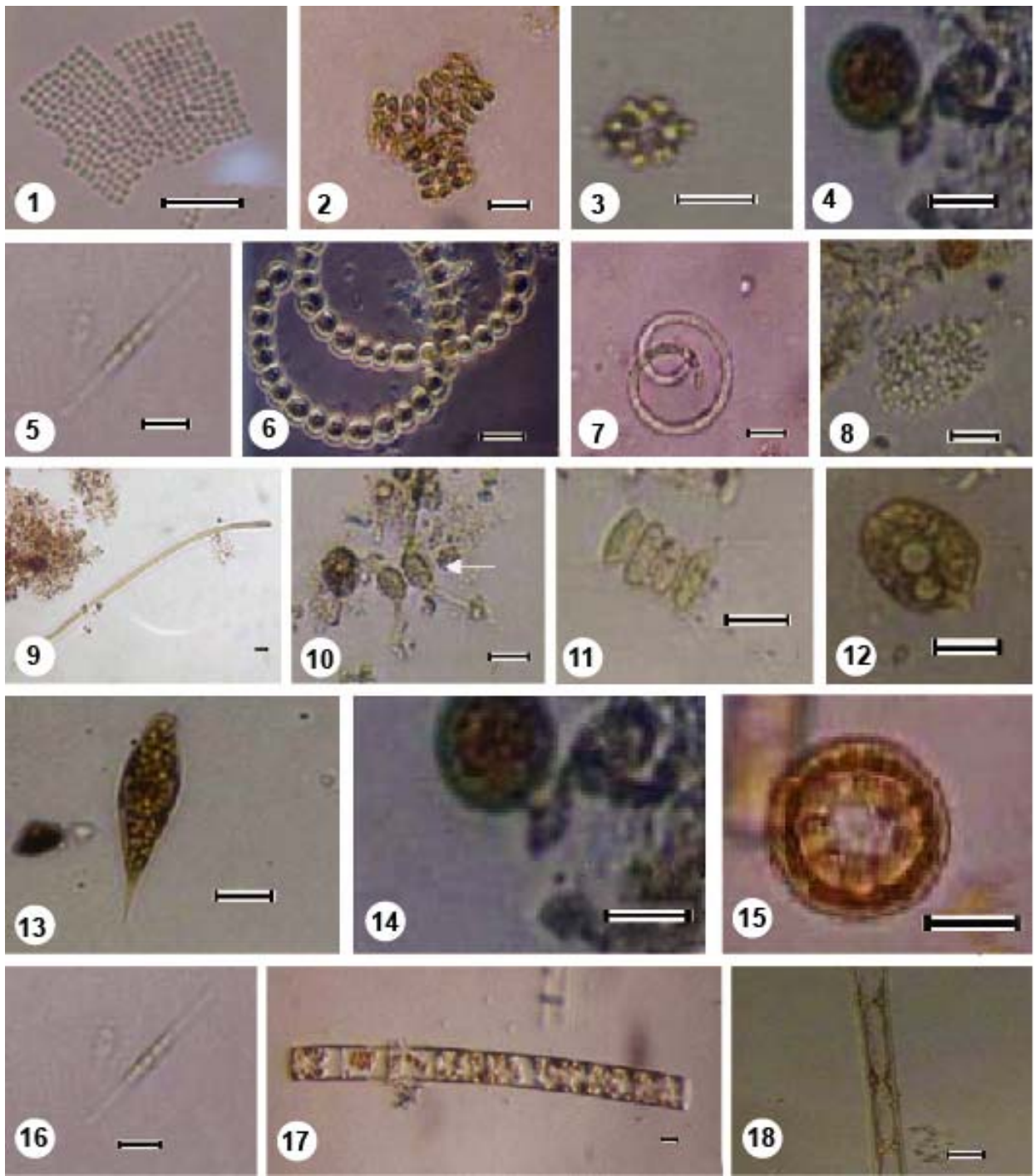

Figs. 1-18: Eighteen representatives of frequently available genera of phytoplanktons observed in various points (K1, K2, K3 and $\mathrm{H}$ ) around the Buriganga river. 1. Merismopedia sp., 2. Crucigenia sp., 3. Coelastrum sp., 4. Trachelomons sp., 5. Nitzschia sp., 6. Anabaena sp., 7. Anabaenopsis sp., 8. Microcystis sp., 9. Oscillatoria sp., 10. Staurastrum sp., 11. Scenedesmus sp., 12. Phacus sp., 13. Euglena sp., 14. Trachelomonas sp., 15. Cyclotella sp., 16. Nitzschia sp., 17. Melosira sp. and 18. Synedra sp. 
After Chlorophyceae, Diatom (Bacillariophyceae) and Blue green alga (Cyanophyceae) showed the remarkable diversity and abundance. The genera Oscillatoria, Raphideonema, Arthrospira, Microcystis, Anabaenopsis of Cyanophyceae and Nitzschia, Synedra, Navicula, Pleurosigma, Cymbella, Cycotella of Bacillariophyceae were recorded during the study.

Point K1, located close to industrial discharge, nine species were recorded. The average abundance of phytoplankton number in this area was $7.7 \times 10^{5}$ Cell/ml ( Table 1). The species dominance was shown by Merismopedia $\left(2.86 \times 10^{6} \mathrm{Cell} / \mathrm{ml}\right)$ from the total number of $1.75 \times 10^{7} \mathrm{Cell} / \mathrm{ml}$. Nitzschia $\left(1.4 \times 10^{3}\right.$ Cell $/ \mathrm{ml})$, Synedra $\left(1.4 \times 10^{3} \mathrm{Cell} / \mathrm{ml}\right)$, Pleurosigma $\left(9.5 \times 10^{2} \mathrm{Cell} / \mathrm{ml}\right)$, Oscillatoria $\left(8.6 \times 10^{2} \mathrm{Cell} / \mathrm{ml}\right)$, Euglena $\left(3.5 \times 10^{2} \mathrm{Cell} / \mathrm{ml}\right)$, Ourococcus $\left(9.5 \times 10^{2} \mathrm{Cell} / \mathrm{ml}\right)$, Strusastrum $\left(2.5 \times 10^{2} \mathrm{Cell} / \mathrm{ml}\right)$, Crucigenia $\left(1.4 \times 10^{2} \mathrm{Cell} / \mathrm{ml}\right)$.

Table 2. Abundance, diversity and dominant taxa of phytoplankton in the water samples of selected points (K1, K2, K3 and $\mathrm{H})$ of the Buriganga river.

\begin{tabular}{|c|c|c|c|c|}
\hline $\begin{array}{l}\text { Sampling } \\
\text { parameters }\end{array}$ & $\begin{array}{l}\text { Sampling point } \\
\text { (K1) }\end{array}$ & $\begin{array}{l}\text { Sampling point } \\
\text { (K2) }\end{array}$ & $\begin{array}{l}\text { Sampling point } \\
\text { (K3) }\end{array}$ & $\begin{array}{l}\text { Sampling point } \\
(\mathrm{H})\end{array}$ \\
\hline $\begin{array}{l}\text { Phytoplankton } \\
\text { No of species }\end{array}$ & 9 & 13 & 21 & 23 \\
\hline $\begin{array}{l}\text { Abundance of } \\
\text { phytoplankton } \\
\text { (No.ML-1) }\end{array}$ & $\begin{array}{c}7240-2681880 \\
(703786.4)\end{array}$ & $\begin{array}{c}60540-3771600 \\
(1303318)\end{array}$ & $\begin{array}{c}110600-17606750 \\
(3142771.6)\end{array}$ & $\begin{array}{c}124670-27926730 \\
(5741871.6)\end{array}$ \\
\hline $\begin{array}{l}\text { Dominant } \\
\text { genus }\end{array}$ & Merismopedia & $\begin{array}{l}\text { Merismopedia } \\
\text { Ankistrodesmus }\end{array}$ & $\begin{array}{l}\text { Merismopedia } \\
\text { Coelostrum } \\
\text { Ankistrodesmus } \\
\text { Nitzschia } \\
\text { Trachaelomonas }\end{array}$ & $\begin{array}{l}\text { Merismopedia } \\
\text { Crucigenia } \\
\text { Ankistrodesmus } \\
\text { Coelostrum } \\
\text { Clostridium } \\
\text { Nitzschia } \\
\text { Tetradesmus }\end{array}$ \\
\hline $\begin{array}{l}\text { Correlation } \\
\text { values of } \\
\text { Merismopedia } \\
\text { btween } \\
\text { abundance in } \\
\text { different } \\
\text { station }\end{array}$ & $\begin{array}{l}0.85(\mathrm{~K} 1-\mathrm{K} 2) \\
0.33(\mathrm{~K} 1-\mathrm{K} 2)\end{array}$ & $0.57(\mathrm{~K} 2-\mathrm{K} 3)$ & $0.78(\mathrm{~K} 3-\mathrm{H})$ & $\begin{array}{l}0.17(\mathrm{H}-\mathrm{K} 1) \\
0.34(\mathrm{H}-\mathrm{K} 2)\end{array}$ \\
\hline
\end{tabular}

At point K2, total 13 species of phytoplankton were recorded and represented by average $1.13 \times 10^{6} \mathrm{Cell} / \mathrm{ml}$. The genus dominance was shown by Merismopedia $\left(3.68 \times 10^{6} \mathrm{Cell} / \mathrm{ml}\right)$ from the total number of $3.25 \times 10^{7} \mathrm{Cell} / \mathrm{ml}$ followed by Ankistrodesmus $\left(6.5 \times 10^{4} \mathrm{Cell} / \mathrm{ml}\right)$, Oscillatoria $\left(2.94 \times 10^{4} \mathrm{Cell} / \mathrm{ml}\right)$ and Crucigenia $\left(1.75 \times 10^{4} \mathrm{Cell} / \mathrm{ml}\right)$. Other genera which were collected and identified form this area are Nitzschia $\left(8.4 \times 10^{3}\right.$ Cell $\left./ \mathrm{ml}\right)$, Clostridium $\left(8.4 \times 10^{2}\right.$ 
Cell $/ \mathrm{ml})$, Microcystis $\left(7.0 \times 10^{3} \mathrm{Cell} / \mathrm{ml}\right)$, Synedra $\left(1.4 \times 10^{3} \mathrm{Cell} / \mathrm{ml}\right)$, Anabaenopsis $\left(7.0 \times 10^{2} \mathrm{Cell} / \mathrm{ml}\right)$, Navicula $\left(3.5 \times 10^{2} \mathrm{Cell} / \mathrm{ml}\right)$, Cymbella $\left(3.5 \times 10^{2}\right.$ Cell $\left./ \mathrm{ml}\right)$, Euglena $\left(3.5 \times 10^{2} \mathrm{Cell} / \mathrm{ml}\right)$ and Cycotella $\left(1.4 \times 10^{2} \mathrm{Cell} / \mathrm{ml}\right)$.

Total 21 genera of phytoplankton were recorded from the point $\mathrm{K} 3$ and the average phytoplankton of this point was $3.14 \times 10^{6} \mathrm{Cell} / \mathrm{ml}$. Like other points, here also Merismopedia $\left(1.68 \times 10^{7} \mathrm{Cell} / \mathrm{ml}\right)$ showed the prime dominance from the total number of phytoplanton of this area $\left(7.85 \times 10^{7} \mathrm{Cell} / \mathrm{ml}\right)$ followed by Nitzschia $\left(7.0 \times 10^{5} \mathrm{Cell} / \mathrm{ml}\right)$, Coelostrum $\left(4.65 \times 10^{5} \mathrm{Cell} / \mathrm{ml}\right)$, Trachaelomonas $\left(3.15 \times 10^{5} \mathrm{Cell} / \mathrm{ml}\right)$ and Ankistrodesmus $\left(1.4 \times 10^{5} \mathrm{Cell} / \mathrm{ml}\right)$, Crucigenia $\left(8.8 \times 10^{4}\right.$ Cell $/ \mathrm{ml})$, Oscillatoria $\left(3.6 \times 10^{4}\right.$ Cell $\left./ \mathrm{ml}\right)$, Cryptomonas $\left(2.1 \times \times 10^{4}\right.$ Cell $\left./ \mathrm{ml}\right)$, Euglena $\left(3.5 \times 10^{2} \mathrm{Cell} / \mathrm{ml}\right)$, Rhodomonas $\left(1.4 \times 10^{4} \mathrm{Cell} / \mathrm{ml}\right)$, Synedra $\left(1.4 \times 10^{3}\right.$ Cell $/ \mathrm{ml})$, Senedesmus $\left(1.05 \times 10^{4} \mathrm{Cell} / \mathrm{ml}\right)$, Clostridium $\left(9.6 \times 10^{3}\right.$ Cell $\left./ \mathrm{ml}\right)$, Microcystis $\left(8.5 \times 10^{3} \mathrm{Cell} / \mathrm{ml}\right)$, Phacus $\left(7.0 \times 10^{3} \mathrm{Cell} / \mathrm{ml}\right)$, Raphideonema $\left(7.0 \times 10^{3}\right.$ Cell $/ \mathrm{ml}), \quad$ Navicula $\left(2.8 \times 10^{3} \quad\right.$ Cell $\left./ \mathrm{ml}\right), \quad$ Cymbella $\left(1.4 \times 10^{3} \quad\right.$ Cell $\left./ \mathrm{ml}\right)$, Chlamydomonas $\left(1.4 \times 10^{3} \mathrm{Cell} / \mathrm{ml}\right)$, Anabaenopsis $\left(1.4 \times 10^{3} \mathrm{Cell} / \mathrm{ml}\right)$, Arthrospira $\left(3.5 \times 10^{2} \mathrm{Cell} / \mathrm{ml}\right)$.

At the point $\mathrm{H}$, total 23 genera of phytoplanktons were recorded and represented by average Cell $/ \mathrm{ml}$. The genus dominance was shown by Merismopedia $\left(2.06 \times 10^{7} \mathrm{Cell} / \mathrm{ml}\right)$ from the total number of $1.43 \times 10^{8} \mathrm{Cell} / \mathrm{ml}$ followed by Nitzschia $\left(7.0 \times 10^{6} \mathrm{Cell} / \mathrm{ml}\right)$, Crucigenia $\left(4.9 \times 10^{5} \mathrm{Cell} / \mathrm{ml}\right)$, Ankistrodesmus $\left(4.2 \times 10^{5} \mathrm{Cell} / \mathrm{ml}\right)$, Senedesmus $(1.25 \times 105 \mathrm{Cell} / \mathrm{ml})$ and Clostridium $\left(1.05 \times 10^{5}\right.$ Cell $\left./ \mathrm{ml}\right)$. Synedra $\left(8.7 \times 10^{4}\right.$ Cell $\left./ \mathrm{ml}\right)$, Chlamydomonas $(7.0 \times 104 \mathrm{Cell} / \mathrm{ml})$, Oscillatoria $\left(3.6 \times 10^{4} \mathrm{Cell} / \mathrm{ml}\right)$, Cryptomonas $\left(2.5 \times 10^{5} \mathrm{Cell} / \mathrm{ml}\right)$, Tetradesmus( $2.4 \times 10^{4}$ Cell $\left./ \mathrm{ml}\right)$, Navicula $\left(1.26 \times 10^{4} \mathrm{Cell} / \mathrm{ml}\right)$, Raphideonema $\left(1.4 \times 10^{4} \mathrm{Cell} / \mathrm{ml}\right)$, Microcystis $\left(1.0 \times 10^{4} \mathrm{Cell} / \mathrm{ml}\right)$, Pleurosigma $\left(8.4 \times 10^{3} \mathrm{Cell} / \mathrm{ml}\right)$, Phacus $\left(8.4 \times 10^{3}\right.$ Cell $\left./ \mathrm{ml}\right)$, Trachaelomonas $\left(8.4 \times 10^{3}\right.$ Cell $\left./ \mathrm{ml}\right)$, Arthrospira $(8.4 \times 103$ Cell $/ \mathrm{ml})$, Anabaenopsis $\left(7.0 \times 10^{3}\right.$ Cell $\left./ \mathrm{ml}\right)$, Coelostrum $\left(7.0 \times 10^{3}\right.$ Cell $/ \mathrm{ml})$, Strusastrum $\left(7.0 \times 10^{3} \mathrm{Cell} / \mathrm{ml}\right)$, Euglena $\left(1.4 \times 10^{3} \mathrm{Cell} / \mathrm{ml}\right)$, Anabaena $\left(3.2 \times 10^{2} \mathrm{Cell} / \mathrm{ml}\right)$.

\section{DISCUSSION}

Many human activities cause pollution of the aquatic environment, modification of the environmental conditions, and thereby changes in the aquatic communities (Mihaljevic et al. 1998). High concentration of heavy metals, viz. $\mathrm{Cr}, \mathrm{Zn}, \mathrm{Pb}, \mathrm{Ni}, \mathrm{Cu}, \mathrm{Cd}, \mathrm{As}$ and other ions like $\mathrm{Cl}^{-}, \mathrm{Na}^{+}, \mathrm{K}^{+}, \mathrm{Ca}^{+2}$, $\mathrm{SO}^{-2}$ were reported from the tannery effluents previously from the identical location in Hazaribagh area by Zahid et al. (2006) and Arias (1998) which are considered as major pollutants of river Buriganga. BOD and COD were high in the first point (K1) and gradually decreased in the rest of the points $\mathrm{K} 2$, K3 and $\mathrm{H}$; on the other hand, dissolved oxygen increased from the first point (K1) to the 
remaining points (Table 1). This indicates that the pollution level gradually decreased from the $\mathrm{K} 1$ to $\mathrm{H}$ points as these are the indicators of water quality (Tsukatani et al. 2003). In this study, we found significantly lower numbers of phytoplankton in comparison with that in the less polluted area of the river, lake and dam water (Verma and Singh 2010, Nowrouzi and Valavi 2011). We found a least diversity and abundance of phytoplankton at the point which is closest to the opening mouth of tannery effluents. The abundance and diversity increased along with the decrease of pollution at the rest of the points (Tables 1 and 2). This result is comparable to other similar studies in South east coast in India, Estuarine Creek in Lagos, Nigeria (Periyanayagi et al. 2007 and Onyema 2007). Merismopedia of Cyanophyceae was found to be dominant. This genus seems to be resistant to polluted environment (Begum and Hossain 1993). Begum (2008) also observed more or less similar abundance of these species in a pond receiving effluents from two textile industries. The taxa recorded in the present study along with their abundance in different points are given in Table 2 in which the abundance of five genera, viz. Crucigenia, Ankistrodesmus, Clostridium, Coelostrum and Senedesmus of Chlorophyceae and Bacilariophycae Nitzschia is evident. For Bacilariophycae, more or less similar observations were reported by Begum and Hossain (1993), and similarly chlorophycean phytoplanktons are common in this habitat. Previously Begum (2008) reported their abundance in polluted water bodies and textile industrial effluents, respectively. Moreover the entire representative genera mentioned above accumulates these heavy metals significantly reported by Aticil et al. (2010). With a few exceptions, among all the groups of phytoplankton recorded, Trachaelomonas of Euglenophyceae showed dominance in K2 station (Table 2). Similar observation was also reported earlier in textile industrial effluents by Begum and Hossain (1993).

Concluding remarks: Altogether 27 genera of phytoplanktons belonging to five families, viz. Cyanophyceae, Bacillariophyceae, Chlorophyceae, Euglenophyceae and Cryptophyceae were identified from four points near the river Buriganga. Merismopedia was the most abundant form in comparison with the presence of other phytoplanktons, viz. Crucigenia, Ankistrodesmus, Clostridium, Coelostrum, Senedesmus and Nitzschia. The abundance of Merismopedia increased gradually along with the decreasing pollutants concentration of the water.

Acknowledgement: The authors are grateful to Science and Technology Ministry for Bangladesh for providing grant to run this study. 


\section{LITERATURE CITED}

ANAND, N. 1998. Indian freshwater microalage. Bishen Sing Mahendrapal Singh Publishers. pp. 9498.

APHA. 1998. Standard Methods for the Examination of Water and Waste water. 21 th Edn., American Public Health Association. Washington DC.

ARIAS, C.R., NISHIZAKI, H., OKUBO, K., AOYAMA, I. and MORI, I.C. 2010. Ecotoxicological characterization of tannery wastewater in Dhaka, Bangladesh. J. Environ. Biol. 31(4):471-475.

ATICIL, T., OBALI, O., ALTINDAG, A., AHISKA, S. and AYDIN, D. 2010. The accumulation of heavy metals $(\mathrm{Cd}, \mathrm{Pb}, \mathrm{Hg}, \mathrm{Cr})$ and their state in phytoplanktonic algae and zooplanktonic organisms in Beysehir Lake and Mogan Lake, Turkey. African J. Biotechnol. 9(4): 475-487.

BEGUM, Z.N.T. and HOSSAIN, M.Z. 1993. Physico-chemical aspects and phytoplankton of a pond receiving textile industrial effluents. J. Biol. Sci. 2(1): 93-99.

BEGUM, Z.N.T. 2008. A taxonomic account on the phytoplankton of a pond receiving textile industrial effluents. Bangladesh J. Plant Taxon. 15(2): 129-139.

DORGHAM, M.M. 1997. Phytoplankton dynamics and ecology in a polluted area on Alexandria Coast, Egypt. Proc. 3 $3^{\text {rd }}$ Int. MEDCOAST Conference, Qawra (Malta). pp 159.

KALAVATI, C., RAMAN, A.V., VAIDEHI, J. and BHARATHI, V.R. 1997. Effects of pollution on planktonic ciliates in Visakhapatnam harbor. Indian. J. Mar. Sci. 26: 68-73.

MIHALJEVIC, Z., KEROVEC, M. and TAVEAR, V. 1998. Macro invertebrate community as an artificial substrate in the Sava river: long-term changes in the community structure and water quality. Biologia Brat. 53: 611-620.

NARENDAR, S.S. 1990. Plankton in relation to coastal pollution at Ennore, Madras coast. Indian J. Mar. Sci. 19: 115-119.

NOWROUZI, S. and VALAVI, H. 2011. Effects of environmental factors on phytoplankton abundance and diversity in kaftar lake. J. Fish. Aquat. Sci. 6: 130-140.

ONYEMA, I.C. 2007. The Phytoplankton Composition, Abundance and Temporal Variation of a Polluted Estuarine Creek in Lagos, Nigeria, Turkish J. Fisher. Aquat. Sci. 7: 89-96.

PERIYANAYAGI, R., SASIKALA, V., VENKATESAN, R., KARTHIKAYEN, R. and BALASUBRAMANIAN, T. 2007. Phytoplankton in relation to pollution in Uppanar Estuary South Coast of India. Resear. J. Environ. Toxicol. 1(3): 153- 157.

RAMAN, A.V. 1995. Pollution effects in Visakhapatnam harbour, India: An overview of 23 years of investigations and monitoring. Helgoland Marine Research. 49: 33-645.

SIVASWAMY, N.S. 1990. Plankton in relation to coastal pollution at Ennore, Madras coast. Indian J. Mar. Sci. 19: 115-119.

TSUKATANI, H., TANAKA, Y., SERA, N., SHIMIZU, N., KITAMORI, S. and INOUE, N. 2003. Validity of Mutagenic Activity as an Indicator of River Water Pollution. Environ. Health Prev. Med. 8: 133138.

VERMA, R. and SINGH, P.S. 2010. Seasonal Distribution of Phytoplankton in Laddia Dam in Sikar District of Rajasthan. Resear. J. Agricul. Sci. 1(4): 366-369.

ZAHID, A., BALKE, K.D. and HASSAN, M.Q. 2006. Evaluation of aquifer environment under Hazaribagh leather processing zone of Dhaka city. Environ. Geol. 50: 495-504.

(Manuscript received on March 8, 2012; revised on June 26, 2012) 